\title{
PENGARUH PEMANFAATAN METODE ANIMASI MULTIMEDIA PADA MATA KULIAH PENGANTAR TEKNOLOGI INFORMASI
}

\author{
Syahrul Mubarak Abdullah \\ Syahrul.Mubarak@umi.ac.id \\ Universitas Muslim Indonesia
}

\begin{abstract}
Abstrak
Penelitian ini bertujuan untuk menyajikan materi secara interaktif disertai animasi, audio, video dan dilengkapi dengan tes formatif berupa latihan-latihan soal. Hasil yang akan dicapai dari pembuatan e-learning ini adalah bahwa mahasiswa dapat termotivasi dalam memahami matakuliah Pengantar Teknologi Informasi. Diharapkan dengan adanya aplikasi ini dapat memudahkan dan meningkatkan kualitas proses belajar mengajar.

Kata kunci: Media pembelajaran, Animasi Multimedia, Pengantar Teknologi Informasi.
\end{abstract}

\section{Pendahuluan}

Di era moderen sekarang ini, kita bisa melihat dengan jelas bagaimana perkembangan teknologi informasi yang begitu cepat. Dimana hal ini sangat mempengaruhi kehidupan manusia dalam arti setiap sisi kehidupan manusia sudah tidak terlepas dari adanya perkembangan teknologi informasi tersebut. Atau orang sering mengatakan bahwa kini manusia sudah mulai tergantung dengan bantuan teknologiinformasi. Dengan adanya teknologi informasi maka manusia dapat melakukan aktivitas dengan efektif dan efisien.

Pendidikan merupakan pendewasaan peserta didik agar dapat mengembangkan bakat, potensi dan keterampilan yang dimiliki dalam menjalani kehidupan, oleh karena itu sudah seharusnya pendidikan didesain guna memberikan pemahaman serta meningkatkan prestasi belajar peserta didik [4].

Kecenderungan pembelajaran yang kurang menarik ini merupakan hal yang wajar di alami oleh para dosen yang tidak memahami kebutuhan dari mahasiswa tersebut baik dalam karakteristik, maupun dalam pengembangan ilmu. Dalamhal ini peran seorang dosen sebagai pengembang ilmu sangat besar untuk memilih dan melaksanakan pembelajaran yang tepat dan efisien bagi pesertadidik bukan hanya pembelajaran berbasis konvensional. Pembelajaran yang baik dapat ditunjang dari suasana pembelajaran yang kondusif serta hubungankomunikasi antara dosen dan mahasiswa dapat berjalan dengan baik.

Berangkat dari hal tersebut multimedia dalam kelas dikembangkan atas dasar asumsi bahwa proses komunikasi didalam pembelajaran akan lebih bermakna (menarik minat mahasiswa dan memberikan kemudahan untuk memahami materi karena penyajiannya dengan multimedia), jika memanfaatkan berbagai media sebagai sarana penunjang kegiatan pembelajaran.

\section{Metode Penelitian}

Penelitian ini merupakan penelitian pengembangan atau dikenal dengan istilah R\&D (Research and Development), yang bertujuan untuk mengembangkan multimedia pembelajaran berbasis komputer berupa media pembelajaran interaktif, yang berorientasi pada produk.

\section{Hasil dan Pembahasan}

Prosedur pengembangan dari penelitian ini adalah sebagai berikut [4].

1. Define

Tujuan dari tahap define adalah untuk menetapkan dan menentukan persyaratan instruksional. Kegiatan yang dilakukan pada tahap define untuk penelitian ini yaitu menganalisis kebutuhan intruksional yang digunakan sebagai acuan untuk pengembangan Programming multimedia learning [3]. Kebutuhan intruksional dalam penelitian ini adalah kebutuhan pembelajaran. Kebutuhan pembelajaran yang dimaksud adalah pemilihan materi Pengantar Teknologi Informasi.

Langkah dari define yang pertama adalah front-end analysis. Pada langkah ini kegiatannya adalah menganalisis permasalahan yang terjadi pada mata kuliah pengantar tekologi informasi. Analisis ini dilakukan dengan cara wawancara. Langkah yang kedua adalah Learned analysis. Kegiatan yang dilakukan pada learned analysis adalah menganalisis permasalahan yang dialami Mahasiswa pada saat mempelajari materi. 


\section{ILKOM Jurnal Ilmiah Volume 9 Nomor 1 April 2017}

2. Design

Tujuan dari tahap ini adalah merancang produk atau membuat desain produk berdasarkan materi instruksional yang telah disebutkan pada tahap define. Langkah dari tahap design yang pertama adalah Constructing criterion-referenced test. Langkah ini merupakan lanjutan dari define. Kegiatan yang dilakukan adalah membuat kerangka programming multimedia learning sebagai media pembelajaran. Kerangka programming multimedia learning digunakan untuk menyusun lembar validasi [2].

3. Develop

Tahap develop dikatakan sebagai tahap penyempurnaan dari tahap-tahap sebelumnya. Langkah dari tahap develop yang pertama adalah expert appraisal. Kegiatan yang dilakukan adalah teknik validasi untuk produk yang telah dikembangkan [3]. Pada penelitian ini kegiatan yang dilakukan adalah memberikan lembar validasi kepada Mahasiswa. Langkah yang kedua adalah developmental testing. Developmental testing adalah tahap uji coba produk pada subjek uji coba yang sesungguhnya. Pada penelitian ini sebagai subjek uji coba adalah kelompok kecil yaitu Mahasiswa fakultas ekonomi dengan jumlah 62 orang.

Jenis data yang terdapat dalam penelitian ini adalah data kualitatif dan data kuantitatif. Data kualitatif berupa komentar dari Mahasiswa terhadap media pembelajaran ini. Sedangkan data kuantitatif didapatkan dari skor hasil angket yang disebarkan Mahasiswa.

Instrumen yang digunakan untuk mengumpulkan data dalam penelitian ini berupa angket. Angket yang digunakan dalam penelitian ini telah disediakan komentar dan kolom penskoran sehingga selain dapat menilai, mahmahasiswa juga dapat berkomentar. Pada kolom penskoran juga sudah tertera skala antara 1-5 yang nantinya responden memberikan tanda centang $(\sqrt{ })$ pada kolom yang dianggap paling sesuai.

Dalam instrumen validasi kepada mahasiwa terdapat rentangan nilai dari $5-4-3-2$ - 1 dengan kriteria perhitungan untuk uji validasi dietapkan dengan skor 5 sebagai tingkat ketercapaian maksimal atau aspek yang dinilai dan skor 1 sebagai tigkat ketercapaian minimal kriteria atau aspek yang dinilai. Berikut penjelasannya :

5 : Sangat Baik

4 : Baik

3 : Cukup

2 : Kurang

1 : Sangat Kurang

Tabel 1 Kriteria Kevalidan dan Hasil Penilaian Validasi Mahasiswa.

\begin{tabular}{|l|l|}
\hline Skala nilai (\%) & Keterangan \\
\hline $85,94-100$ & Sangat valid \\
\hline $67,19-85,93$ & Valid \\
\hline $48,44-67,18$ & Kurang valid \\
\hline $25-48,43$ & Sangat kurang valid \\
\hline
\end{tabular}

(Sumber : Diadaptasi dari Suryabrata dalam Agustina, 2011) [4]

Data kualitatif dianalisis dengan cara mengumpulkan komentar-komentar yang didapat untuk dijadikan bahan pertimbangan dalam melakukan revisi terhadap produk. Data kuantitatif didapat dari penskoran pada angket oleh Mahasiswa. Data kuantitatif ini dianalisis dengan menggunakan rumus persentase sebagai berikut :

$$
P=\frac{\sum x}{\sum x i} \times 100 \%
$$

Rumus menghitung persentase kevalidan variabel. (Sumber: Di adaptasi dari Suryabrata dalam Agustina, 2011) [4]

Keterangan:

$\begin{array}{ll}\mathrm{P} & =\text { Persentase Kevalidan } \\ \Sigma \mathrm{X} & =\text { jumlah skor keseluruhan jawaban per item } \\ \Sigma \mathrm{Xi} & =\text { jumlah total skor maksimal per item } \\ 100 \% & =\text { konstanta }\end{array}$




\section{ILKOM Jurnal IImiah Volume 9 Nomor 1 April 2017}

Mahasiswa yang menjadi sasaran uji validitas adalah kelas AWP5 dan AWP8 Fakultas ekonomi UMI yang berjumlah 62 mahasiswa. Angket yang diberikan kepada Mahasiswa terdiri atas 10 aspek penilaian. Berikut rekapitulasi data hasil uji kelompok Mahasiswa yang dapat dilihat pada Tabel.

Tabel 2 Rekapitulasi Data Hasil Uji Coba Kelompok Mahasiswa

\begin{tabular}{|c|c|c|c|c|c|}
\hline No. & Aspek yang dinilai & $\Sigma x$ & $\Sigma \mathbf{X} \mathbf{i}$ & $\%$ & Keterangan \\
\hline 1 & Tampilan media menarik & 2450 & 3100 & 79.03 & Valid \\
\hline 2 & $\begin{array}{l}\text { Media Pembelajaran ini sudah jelas dan } \\
\text { mudah dipahami }\end{array}$ & 2640 & 3100 & 85.16 & Valid \\
\hline 3 & $\begin{array}{l}\text { Isi materi gambar perspektif dalam media ini } \\
\text { sudah lengkap }\end{array}$ & 2060 & 3100 & 66.45 & Kurang valid \\
\hline 4 & $\begin{array}{l}\text { Bentuk, Ukuran, dan jenis font yang } \\
\text { digunakan sudah jelas }\end{array}$ & 2760 & 3100 & 89.03 & $\begin{array}{l}\text { Sangat } \\
\text { Valid }\end{array}$ \\
\hline 5 & $\begin{array}{l}\text { Bahasa yang digunakan dalam media ini } \\
\text { sudah jelas }\end{array}$ & 2440 & 3100 & 78.70 & Valid \\
\hline 6 & Media pembelajaran ini mudah digunakan & 2550 & 3100 & 82.25 & Valid \\
\hline 7 & $\begin{array}{l}\text { Kesesuaian media persentasi sebagai media } \\
\text { penunjang selain buku ajar }\end{array}$ & 2420 & 3100 & 78.06 & Valid \\
\hline 8 & $\begin{array}{l}\text { Media pembelajaran ini dapat digunakan } \\
\text { dalam proses belajar mengajar pengantar } \\
\text { teknologi informasi }\end{array}$ & 3050 & 3100 & 98.38 & $\begin{array}{l}\text { Sangat } \\
\text { Valid }\end{array}$ \\
\hline 9 & $\begin{array}{lrr}\text { Anda senang menggunakan media } \\
\text { pembelajaran ini }\end{array}$ & 2400 & 3100 & 77.41 & Valid \\
\hline 10 & $\begin{array}{l}\text { Setelah menggunakan media pembelajaran } \\
\text { ini, ada faham tentang materi perkuliahan } \\
\text { pengantar teknologi informasi }\end{array}$ & 2480 & 3100 & 80 & $\begin{array}{l}\text { Sangat } \\
\text { Valid }\end{array}$ \\
\hline \multicolumn{2}{|c|}{ Jumlah } & 25250 & 31000 & 81.45 & Valid \\
\hline
\end{tabular}

Berdasarkan perhitungan yang telah tercantum pada Tabel tersebut diperoleh hasil uji coba kelompok kecil dengan nilai $81,45 \%$. Nilai tersebut menunjukkan bahwa produk pengembangan Programming Multimedia learning termasuk dalam kriteria valid.

\section{Data Kualitatif}

Data kualitatif untuk produk Programming multimedia learning ini diperoleh dari komentar dari para mahasiswa. Data kualitatif digunakan sebagai bahan pertimbangan dalam merevisi produk Programming multimedia learning kami kedepannya. Penyajian data kualitatif yang diperoleh dari mahasiswa dapat dilihat pada Tabel dibawah.

Tabel 3 Rekapitulasi Data Kualitatif dari Mahasiswa

\begin{tabular}{|c|c|c|c|}
\hline No. & Validator & Hasil & Komentar \\
\hline 1. & Mahasiswa & $81,45 \%$. & $\begin{array}{l}\text { a) Kejelasan teks mudah dipahami } \\
\text { b) Huruf sudah jelas namun terlalu besar } \\
\text { c) Programming multimedia learning ini membuat } \\
\text { lebih bersemangat belajar karena pembelajaran } \\
\text { jarang yang menggunakan aplikasi lebih banyak } \\
\text { power point } \\
\text { d) Media pembelajaran sangat flekibel karena dapat } \\
\text { dilihat diluar pembelajaran dikelas } \\
\text { e) Animasi menarik } \\
\text { f) Suara musik kurang jelas terdengar } \\
\text { g) Suara sangat merdu } \\
\text { h) Animasi tergolong jelas namun bisa dibuat lebih } \\
\text { i) Mreatif } \\
\text { j) Sangat menarik karena media pembelajaran } \\
\text { dilakukan dalam teknologi jaman sekarang } \\
\text { k) Musik mengganggu konsentrasi }\end{array}$ \\
\hline
\end{tabular}




\section{ILKOM Jurnal Ilmiah Volume 9 Nomor 1 April 2017}

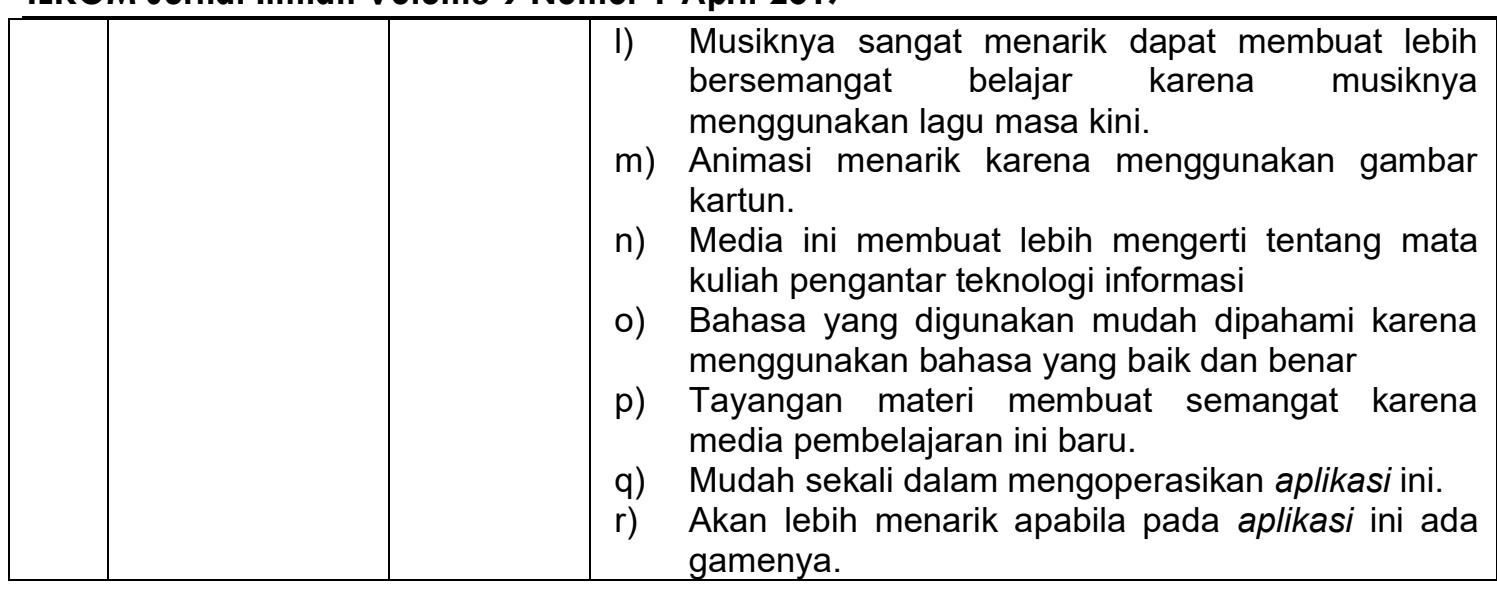

\section{Pembahasan}

Berdasarkan analisis data kuantitatif dari lembar validasi dari Mahasiswa produk programming multimedia learning ini termasuk dalam kriteria valid dengan nilai $81,45 \%$.

Aplikasi programming multimedia learning sebagai media pembelajaran memang memiliki fungsi utama yaitu membantu Mahasiswa dalam mempermudah memahami materi yang bersifat abstrak. Hal ini sesuai dengan pernyataaan Supriatna (2009) yaitu, penggunaan media dalam pembelajaran dapat membantu anak dalam memberikan pengalaman yang bermakna bagi mahasiswa. Penggunaan media dalam pembelajaran dapat mempermudah mahasiswa dalam memahami sesuatu yang abstrak menjadi lebih konkrit [4].

Keunggulan media pembelajaran programming multimedia learning ini antara lain : (1) Programming multimedia learning ini tidak memerlukan biaya untuk mengaksesnya karena sifatnya offline. (2) Programming multimedia learning ini tidak memerlukan koneksi internet untuk menggunakannya, sehingga pengguna tidak direpotkan ketika terjadi ketidakstabilan signal pada provider yang digunakan; (3) Programming multimedia learning ini menyajikan materi Pengantar teknologi informasi yang sudah dilengkapi dengan animasi; (4) Programming multimedia learning ini dikemas dengan memadukan unsur multimedia (teks, gambar, suara) sehingga dapat membuat Mahasiswa lebih tertarik; (5) Programming multimedia learning ini menyediakan menu latihan sehingga mahasiswa dapat mengukur tingkat pemahamannya terhadap materi Pengantar teknologi informasi; (6) Programming multimedia learning ini bersifat fleksibel yang berarti dapat digunakan di mana pun dan kapan pun pengguna berada [1].

Kelemahan media pembelajaran Programming multimedia learning ini antara lain: (1) Programming multimedia learning ini hanya dapat berjalan dengan baik pada PC (Personal Computer); (2) Programming multimedia learning ini memiliki animasi yang masih terbilang kasar dari segi resolusinya [1].

\section{Kesimpulan dan Saran \\ Kesimpulan}

Berdasarkan hasil validasi dari beberapa Mahasiswa dapat disimpulkan aplikasi multimedia ini layak untuk digunakan sebagai media pembelajaran pada materi pengantar teknologi informasi dengan beberapa revisi. Revisi dilakukan berdasarkan data kualitatif sehingga meningkatkan kualitas dari produk aplikasi learning sebagai media pembelajaran pada materi pengantar teknologi informasi.

\section{Saran}

Saran yang diberikan terdiri atas saran pemanfaatan, saran diseminasi dan saran pengembangan produk lebih lanjut. Saran pemanfaatan produk antara lain : (1) Pemrogramming Multimedia ini dapat berjalan optimal pada Personal Computer berspesifikasi normal default; (2) Pemrogramming Multimedia ini hanya berfungsi sebagai pendamping buku atau suplemen sehingga dalam penggunaannya sebaiknya tidak terlepas dari penggunaan buku paket.

\section{Daftar Pustaka}




\section{ILKOM Jurnal IImiah Volume 9 Nomor 1 April 2017}

[1] Jogiyanto. 2005. Analisis \& Desain Sistem Informasi : Pendekatan Terstruktur Teori dan Praktek Aplikasi Bisnis : Penerbit ANDI. Yogyakarta.

[2] Presman, Roger S. 2002, Software Engineering: A Practitioner's Approach. Diterjemahkan oleh LN Harnaningrum dengan judul Rekayasa Perangkat Lunak: Pendekatan Praktisi (Buku I). Andi, Yogyakarta.

[3] Waryanto, Hadi.2008. Multimedia Interaktif dalam Pembelajaran. (Online), (staff.uny.ac.id//Multimedia\%20Interaktif\%20Dalam\%20Pembelajaran), Akses pada jam 05.40 AM tanggal 1 Mei 2015.

[4] Agustina, L., 2011. Pengaruh Motivasi Belajar Siswa Terhadap Prestasi Belajar IPA Di Sekolah Dasar. Jurnal Penelitian, Vol.1: No.2. http://www.jurnal.upi.edu/file/8-Ghullam-Hamdu. 